\title{
The Effectiveness of 9 Years Compulsory Education Policy towards Education Enhancement of Child Workers
}

\author{
Atta Irene Allorrante \\ Department of Public Administration \\ Hasanuddin University \\ Makassar, Indonesia \\ attairena@gmail.com
}

\begin{abstract}
The objective of this research is to determine the effectiveness level of 9 years compulsory education program in terms of increasing the accessibility of school age children to obtain education which finally can affect to the reduce of child workers. This research uses qualitative approach, whether in data collecting and data analyzing. Primary data was found through a deep interview with some stakeholders and also the child workers which completed with the real observation on the child workers activity. Then, the secondary data was found by documents and statistic data from related institutions. This research shows that the 9 years compulsory education program in Makassar is not effective yet. This conclusion is based on the result of data analysis which showing that: (1) the amount of the school age children which still cannot access the education are relatively big. Because until 2009 , the school participatory number (APS) just reaching 87 percent, which this number is not having many different with the number of the previous years; (2) the amount of child workers which do not access the education is relatively big, which means the 9 years compulsory education policy is not attract the willing of those child workers to access the education; and (3) the curriculum which provided in 9 years compulsory education is not oriented to the preparation of the students to directly involve in workspace at the young age yet.
\end{abstract}

Keywords: effectiveness program; education policy; policy evaluation

\section{INTRODUCTION}

In Indonesia, statistic data on child workers in the age of less than 15 years old is not available completely and accurately, because the unavailability of information or data that can indicate the amount or even the dispersion of the child workers itself. The provided data are in forms of national job survey (Sakernas) to the population in age range between 10-17 years old. Although the Sakernas data did not inform accurately about the amount or dispersion of child workers, but that data informs about the main work field that dominantly using child workers, the most kind of work that the child workers do, work capacity and the amount of salary that the child workers receive.

According to the National Committee on Child Protection (Komnas Perlindungan Anak), in 33 Provinces, the amount of child workers is increasing, where 3,2 million in 2006 is increasing to 4,8 million in 2007 and in 2008 is predicted to be 6,3 million. This prediction based on the pattern that happens in the previous years. About 20-30 percent of the school breaks child are directly enter to work sector and becoming workers, mainly the junior high school level breaks.

National Committee on Child Protection data is showing that in 2006 there are 10,8 million child experiencing school break and in 2007 increased to 11,7 million in elementary phase until senior high school. Those data are obtained through the data collection in 33 provinces that held by child protection institution in every province. This showing that almost 12 million of children are leaving the school. The unclear realization of the free education program is absolutely cannot reduce the very high number of school breaks. The number of school breaks is relatively high, shown by data from national education department in 2007, there are 1.039.067 of the school age child have to leave their education. Education is the main road for the promotion of universal human values, the quality of human resources and respect for cultural diversity [1]

Makassar is the one of the example which common with child workers matters. The reality of child workers in Makassar is very concrete because of some of them are working at public spaces like streets, worship places, crowded places and etc. This means that the existence of child workers was very close to the Makassar's citizens life, because of their existence is visible and realized by the citizens. The existence of child workers in public spaces is conducting the more complexity of their problems. Problems that appear is not just their condition which have not in productive age yet or still in school age, but also are associated with the other social problems.

Their activities are disturbing the common order, reduce the cosines, endangered their health, accident, they are also easy to be associated with criminals, exploitation, sexual harassment and etc. But until now, the accurate and actual data about the child workers is not available yet. Data which provided by Makassar Social Agency (Dinas Sosial) shows that the number of street children in 2008 is about 876 people. From that number, there are 600 people which categorized in school age. While data of child workers number which disperse in another sector where their work field are not on the street has not available yet. They are the

Corresponding author: Atta Irene Allorante 
scavengers (scavengers in landfill or in residence), housemaids, workers in fisheries sector (fish auction places), industrial sector workers, prostitution and etc. Then, the amount of child workers in Makassar is predicted to be larger if the data from the other sectors are provided.

The result of International Labor Organization (ILO) research in 2005 showing that about 4,18 million (19\%) of school age child in Indonesia are experiencing of school breaks and becoming child workers. In amount of 19 percent of children in age below 15 years old is not accessing the school and decided to be a worker. ILO survey are involving 1.200 family in five provinces, that is East Java, North Sumatera, East Kalimantan and South Sulawesi. Based on that survey, Makassar is having the bigger number of school breaks child in Indonesia. The number of school breaks in Makassar according to data from SUSENAS in 2007 towards the children in age range between 7 until 18 years old is about 3.183 people.

Rustamto [2] states that the need to formulate a clear concept of how the actual form of free education offered. Because it needs to be understood that public opinion is already patterned if free education means free of any kind of payment concerning the education of his child.

Though freeing the community completely from the intervention of educational financing, it is difficult to do now considering the limited facilities of educational unit and to meet it requires substantial funds.

In Makassar, education policy is still becoming one of the priority and some policies toward education in school age with some supporting program. For example, 9 years compulsory education is supported with another policy that is the distribution of school operational fund (BOS), the forming of education council, increasing of children reading interest, non-formal education and also free education program for 9 years education level. Those policies are the derivative policy of International Education for All convention (EFA) and acted by policy in form of local regulation (PERDA) Makassar city number 3, 2006 about the education enforcement [3].

Parallel with the education policy, especially education in school age in Makassar, it is absolutely facing the quite serious challenges, reminding the population growth of school age citizens are relatively increased. It happened because of some factors like Makassar as the destination of urbanization and as the center of East Indonesia Region (KTI). However, the condition of supportive facility is not sufficient yet, that is in elementary school, the number of schools is 449 units and students are 136.560 students with 4.127 teachers. In Junior High School level, there are 165 schools and 55.997 students with 4.025 teachers (Makassar in number 2008). These data show that, the imbalance between education supporting facilities with the acceleration of school age children which grow faster. Urban area (city) is the center of some activities like economy, socio-culture and politics so the growth in urban is relatively rapid with the significant growth. Population growths in urban area generally caused by the urbanization, whether it becomes the permanent resident or even make the city only for a place to gather income.

According to the explanation above, so it is needed to do an evaluation towards the success of 9 years compulsory education achievements. Some problems which considered to be evaluated is the response of child workers towards the 9 years compulsory education itself, the effect of 9 years compulsory education towards child workers and the effect of 9 years compulsory education policy towards the selfpotential development of child workers in Makassar. Beside that it is important to know about the parental support towards the child workers to be involved in education and the implementation of 9 years compulsory education policy.

\section{RESEARCH METHOD}

This research was held in Makassar. This research using qualitative approach with the case study model which done by observation, documentation and deep interview method. Data tabulation and analysis in big line are consist of descriptive analytic and frequency. Frequency analysis shows that, the number of incidents (frequency) that happens and observes, while descriptive analytic consists of the average value and variance.

\section{RESULT AND DISCUSSION}

At the basic source of human resource development (human resources Development), there are two important aspects as inputs in the improvement of health factors (including nutrition) and educational factors (in general). [4]

In principle, the policy implementation is the way for a policy to achieve its goals, but to understand the influence of 9 years compulsory education policy implementation towards the enhancement of child workers education especially in elementary school phase. The influence of 9 years compulsory education policy towards the enhancement of child workers education mostly that is 27 people $(90 \%)$ of informant said that it is less influential. 9 years compulsory education and free education in decision in elementary school with the average value 2,6 (less influential). The less influential of 9 years compulsory education and free education towards the child workers education is because of the lack of information about that policy. Then in free education, it is free only for the tuition fee, while the transport, uniforms, and other expenses are difficult to be fulfilling with the family income. Family income is only for daily life expenses and even it is not 
enough, even less to cover their school necessary. Mostly in number 27 people (70\%) informant said that parents sometimes asking them for going to school because of the existence of 9 years compulsory education and does not pay for the tuition fee with the average value of 3,30 (sometimes asking by the parents). Then mostly, in number 16 people $(53,3 \%)$ informant said that, if only the 9 years compulsory education and free education are not existed, so the possibility for them to be still in elementary school is very small with the average value 2,47 (small possibility to be still in school). This indicates the big influence of 9 years compulsory education and free education toward their decision for school matter. Most of them in number of 21 people $(70 \%)$ of informant stated that the less influence of 9 years compulsory education and free education towards their motivation for having school with the average number 2,90 (less influential).

From the average value calculation of the effectiveness child workers education, average value obtained is 2,47 with the poor result (low category). This means the child workers in elementary school level at Makassar is not effective in accessing education enhancement (low) towards the 9 years compulsory education policy. The low contribution of 9 years compulsory education policy implementation towards the child workers is caused by family economic factor. Because of that, the local government of Makassar has to revitalize the countermeasure child workers policy implementation program through social rehabilitation effort program which held by local government of Makassar in collaboration with child social protection institution, Beruga Sayang Anak.

Child social protection institution is the social house official institution which aims to, first: giving advocacy to the street children who involved in law matters. Second: conducting for empowerment to the street children and its family. Third: giving religious counseling and social knowledge. Fourth: as the service center for the child worker. Fifth: as temporary termination (stopover) for the child workers which is not able to connect with their family. Then the program implementation is the enhancement program for workers through "Back To School" program and "Live Skill" program which is as the program of Departemen Sosial RI (Social Department of Indonesia).

"Back to School" program is the recovering program to re-enter the child workers in school age between 6-15 years old to school, which they've experiencing school breaks because of cost matters by their parents. This happens on elementary school level and junior high school level. "Live Skill" program is the skill upgrading program for the productive age child between 15-20 years old. This program was held by Makassar Social Agency (Dinas Sosial), selection phase, assistants (social workers), counseling and reporting. In cooperation with Handayani Course Institution Makassar, the automotive skill course for the boys and sewing skill course for the girls.

Based on data tabulation, has been obtained that the effect of 9 years compulsory education policy towards education enhancement of the child workers which included in package A, as shown above that the effect of 9 years compulsory education towards the education enhancement of child workers are: (1) Mostly, in number 12 people $(40,3 \%)$ informants stated that 9 years compulsory education is less influential and the effect of free education towards their decision to study in package $\mathrm{A}$ is in average 2,10 (less influential). (2) Mostly, in number 15 people $(50,0 \%)$ informants stated that parents usually asking them to school because of the existence of 9 years compulsory education policy and do not pay the tuition fee with the average value 1,77 (usually to ask). (3) Mostly, in number 11 people $(36,7 \%)$ informants stated, if only the 9 years compulsory education and free education are not existed, it must be the did not access the education in package $\mathrm{A}$, with the average value 2,13 (certainly not going to school). This indicates the less influence of 9 years compulsory education and free education towards their decision to access the education itself. (4) Mostly, in number 14 people $(46,7 \%)$ informants stated that the effect of 9 years compulsory education and free education towards their school motivation in average value of 1,57 (less influential).

From the average value calculation of the effectiveness of child workers education enhancement, average value obtained is on 2,43 with the good category (less). This means that the child workers in package A at Makassar do not getting education enhancement or in another mean the 9 years compulsory education is less effective. According to the data tabulation, obtained that the effect of 9 years compulsory education towards the education enhancement for the child workers in junior high school level, as shown at the table above, shows that the effect of 9 years compulsory education towards the child workers education are: (1) Mostly, in number 11 people (36,7\%) informants stated that the effect of 9 years compulsory education and free education towards their willing to access the junior high school is in average value 2,27 (less effective). (2) Mostly, in number 11 people $(36,7 \%)$ informants stated that parents usually asking them to school because the existence of 9 years compulsory education and do not pay the tuition fee, with the average number 2,13 (rarely asking by their parents). (3) Mostly, in number 13 people (43,3\%) informants stated that if only the 9 years compulsory education and free education is not existed, so the possibility of those children to stay in school is small with the average number 2.10 (small possibility to stay in school). This indicates about how big those policies affected their decision to school. (4) Mostly, in number 13 people 
$(43,3 \%)$ informants stated that the big influence of 9 years compulsory education and free school towards their motivation to school with average number 2.13 (less affected).

\section{IV.CONCLUSION}

Based on the responsivity analysis result, effectiveness and implication of 9 years compulsory education towards child workers, result obtained showing that, 9 years compulsory education policy is less effective towards the enhancement of child workers education. This has been measure using 9 years compulsory education effect indicator to the school decision, parental support, possibility of changes if those policies do not exist and the influence of those policies towards their school motivation. The result showing that in school decision it is less effective, lack of parental support, big possibility of school breaks if those policies are not existed and also small affected to their school motivation.

Based on the responsivity analysis result, effectiveness and implication of 9 years compulsory education towards child workers, so the suggestions that could be stated are: It is better for Education Agency (Dinas Pendidikan) if they are inviting all of the child workers with their parents to give them socialization/briefing about 9 years compulsory education and free education policy and the importance of it for every human. In this activity should be involving Education Agency (Dinas Pendidikan) and local champions. The execution held in every district especially approaching to the admissions time of new students. it should be hold at the area with many of child workers and rural area. The implementation of 9 years compulsory education is not only in conceptual level, but need a commitment from all of the stakeholders especially from executive side. This is one cause factor of the failure implementation of this program, so the result does not reach maximum result. Because of that, need a firm action by the local government to implement the exist regulation with giving sanctions to every stakeholder who do not obey the regulation.

\section{REFERENCES}

[1] O.S. Prijono, Empowerment: concept, policy and implementation (Pemberdayaan: konsep, kebijakan dan implementasi), Jakarta, Cides. 1996

[2] Rustamto. "Free Education, A Political Dilemma" (Pendidikan Gratis, Suatu Dilema Politik). Newspaper: Fajar Makassar. 2007

[3] Local Regulation of Makassar City, Number 3 Year 2006, Regarding the implementation of education.
(Peraturan daerah Kota Makassar, Nomor 3 Tahun 2006, tentang penyelenggaraan pendidikan)2006

[4] P. Tjiptoherijanto, Human resources in national development, Jakarta: Faculty of Economics UI Publisher. (Sumber daya manusia dalam pembangunan nasional, Jakarta: Lembaga penerbit Fak Ekonomi UI) 1986 